\title{
French and Other Selected European Perspectives on Asylum
}

\author{
Liisa Coulombe
}

This is a report of a conference, "Les réfugiés en France et en Europe: Quarante ans d'application de la Convention de Genève 1952-1992," which took place on June 11-13 in Paris, organized by the Office francais de protection des réfugiés et apatrides (OFPRA).

Any conference held in the international conference centre in Paris, a showcase of the French Foreign Affairs Department, could only be an official one. An alternative gathering convened simultaneously. ${ }^{1}$ But since the French readily agree to disagree, some divergent perspectives on their past and present government policies and services were courteously voiced at this first ever OFPRA conference-on the rostrum, that is, since the masses were kept silent and their written questions filtered on occasion.

A VIP set-up was not foolproof. Some distinguished government officials and guests were forced, along with others, into an overflow room to watch the proceedings on a screen. Like states, the conference had a welcoming staff that did not exercise border control in the early hours of the influx.

\section{Statutory Refugees in France: Potent Symbols}

The conference opened on a solemn note. The heroism of individual and collective conviction and flight from persecution was invoked. A French Foreign Affairs official lyrically recalled the preamble of the 1946 French Constitution to herald refugees, symbols of its intangible principles. A clear distinction between statutory refugees and other shades of economic migrants disguised as asylum seekers was therefore in order. Subsequent presentations clearly focused on the former category. Hence, virtually no mention was made of North and especially West Africans, who are by far the largest group of current asylum seekers in France. In fact, the conference was somewhat of a festive occasion, with the ambitious goal of looking back on forty years of OFPRA - an independent body linked to Foreign Affairsupholding the 1951 Geneva Convention. There was much back-patting. Des̄pite the conference's title, there was only a cluster of thematic studies on non-French situations. Some of these presentations were bent on showing both local dynamics and possible migratory flows to France, such the transit of the Commonwealth of Independent States (CIS) nationals through Poland.

To the embarrassment of the Interior and Social Service Department representatives, competent research underscored blatant lack of resources and integrated policy planning in medical, psychological and local socioeconomic services available to statutory refugees, especially asylum seekers. Much attention was rightly focused on crucial integration phases concerning restrictive world provisions. Examples provided were common to other European contexts, namely Germany, and could also be found in varying degrees in North American and antipodean societies.

\section{Implications of the Emerging Institutional Setting in Europe}

"Harmonization," the buzzword in asylum policies, remained a moot issue throughout proceedings that dealt mostly with inward-looking positions of certain governments. However, mention was made of the European Council's (EC) recent request to head in this direction. Migration, the third pillar of the February 1992 Maastricht agreement, is left to intergovernmental cooperation and not integrated into community affairs.

Researchers appealed for the lifting of confidentiality of nationally-compiled statistics on migratory flows in EC space.
The next step would be to require that sufficient resources be earmarked for gathering missing comparative data and for undertaking studies. In the meantime, the forthcoming publication of the conference papers will offer a wealth of information for beneficial comparative analysis.

\section{A Plea for Actlon on the Periphery of the European Community}

In an opening presentation, Professor A. Zolberg spoke of the shakiness of the Geneva Convention regime, yet others reaffirmed its continuing effective features during and in the aftermath of the Cold War. Most spoke of the need for change through concerted regional approaches, especially in Europe.

EC integration in the Maastricht framework calls for tightening control at outside borders as internal ones disappear. The last prophetic words came from French Professor Pierre Hassner on Europe's responsibility in dealingholistically with the Yugoslavian situation as an integral part of putting double standards aside: "We must not barricade ourselves behind our prosperity." ${ }^{2} \square$

\section{Notes}

1. "Droit d'asile. Appel à témoins." See Philippe Bernard, "Des réfugiés aux immigrés," Le Monde, Paris, June 13, 1992.

2. See Pierre Hassner, "De Maastricht à Sarajevo," Liberation, Paris, May 27, 1992 .

Liisa Coulombe is a Ph.D. candidate at the Department of International Relations, Research School of Pacific Studies, Australian National University in Canberra. 